\title{
Effect of simvastatin on c-myc, cyclin D1 and p53 expression in DMBA-induced breast cancer in mice
}

\author{
Behnaz Karimi ${ }^{1}$, Mahboobeh Ashrafi ${ }^{1 *}$ (iD , Malihe Masoudian² \\ 1. Division of Biochemistry, Department of Basic Sciences, School of Veterinary Medicine, Shiraz University, Shiraz, Iran \\ 2. Division of Biotechnology, Department of Pathobiology, School of Veterinary Medicine, Shiraz University, Shiraz, Iran
}

\begin{abstract}
Introduction: Recently, the therapeutic and antioxidant effects of simvastatin on 7,12-dimethylbenz[a] anthracene (DMBA) induced breast cancer have been studied. To gain further understanding of the molecular mechanisms of simvastatin, this study investigated its effects on the expression of c-myc, cyclin D1 and p53 in normal mammary glands and tumors.
\end{abstract}

Methods: Female albino mice were divided into two groups: 1) $\mathrm{N}$ group, healthy mice without DMBA and 2) D group, mice with DMBA administration. After the appearance of tumors, D group mice are subdivided into 3 groups, as control (C), simvastatintreated group (S) which received $80 \mathrm{mg} / \mathrm{kg} /$ day, orally and tamoxifen-treated group (T) with $50 \mathrm{mg} / \mathrm{kg} / \mathrm{day}$, orally. After 4 weeks, animals were sacrificed. Also, the tumors and normal mammary glands were removed for histopathological evaluations and analysis of gene expression by qRT-PCR.

Results: The results showed the up-regulation of c-myc and cyclin D1 in tumors of the control group compared with mammary glands of the $\mathrm{N}$ group. Similar to tamoxifen, the simvastatin treatment could normalize the expression of c-myc and cyclin D1; however, the expression of p53 did not change in the treated groups.

Conclusion: Down-regulation of c-myc and cyclin D1 in treated tumors with simvastatin could be a possible molecular mechanism for its therapeutic effects in DMBA-induced breast cancer in mice.

http://dx.doi.org/10.32598/ppj.24.2.70

\section{Keywords:}

Breast cancer;

Simvastatin;

Cyclin D1;

C-myc;

P53

\section{* Corresponding author: \\ Mahboobeh Ashrafi \\ Email: \\ mashrafi@shirazu.ac.ir \\ Tel: +98 (71) 36138907 \\ Received 3 November 2019; \\ Received in revised form 21 \\ March 2020; Accepted 27 \\ March 2020}

\section{Introduction}

One of the most common invasive cancers diagnosed among women is the breast cancer. It was estimated that 14.9 million new cases of breast cancer were identified in 2012 which are expected to reach up to 22 million within the next two decades (Ghoncheh et al., 2016). Breast cancer must be considered as a multifactorial disease with gene-environment interactions (Martin and Weber, 2000). A better understanding of molecular mechanisms involved in cancers is essential for improving of our knowledge and developing new therapeutic protocols against cancers (Ashrafi et al., 2012). Mutations in the protooncogenes and tumor suppressor genes are termed as gain-of-function and loss-of-function mutations which overall lead to uncontrolled cell proliferation (de Leon, 1994). 
One of the most well-known tumor suppressor genes is p53. The classic role of p53 is known as cell cycle arrest and apoptosis. The p53 mutations are frequent events in more than $50 \%$ of many different cancers (Ozaki and Nakagawara, 2011). On the other hand, c-myc, as a cellular proto-oncogene, regulates the expression of gene families involved in cell growth, migration, metastasis and apoptosis (Takwi et al., 2012; Miller et al., 2012). Also cyclin D1, as another oncogene, plays a crucial role for $\mathrm{G} 1 / \mathrm{S}$ transition in cell cycle by activation of cyclin-dependent kinases (CDKs) 4 and 6 which lead to phosphorylation of retinoblastoma (Kim and Diehl, 2009). This ability proves its oncogenic potential for developing neoplastic transformation (Musgrove et al., 2011). The 7,12-dimethylbenz[a] anthracene (DMBA), one of the polycyclic aromatic hydrocarbons, is used widely for the induction of mammary tumors in rodents (de Oliveira et al., 2015). Reactive metabolites of DMBA could form DNA adducts and induce DNA mutation. Moreover, elevated expression of cyclin D1 and cmyc has been found in DMBA-induced mammary tumors (Currier et al., 2005).

Simvastatin belongs to the first-line agents for hypercholesterolemia, commonly called statins. The lipid-lowering effect of statins is based on the inhibition of the 3-hydroxy-3-methylglutarylcoenzyme A reductase (Stancu and Sima, 2001). Studies have also reported that statins possess anticancer activity through anti-proliferative, proapoptotic, anti-metastatic and anti-angiogenic properties (Chan et al., 2003; Dulak and Józkowicz, 2005; Campbell et al., 2006; Shen et al., 2015). Some clinical evidences have shown that statin therapy has protective effects against breast cancer and also reduces breast cancer mortality (Graaf et al., 2004; Beckwitt et al., 2018). Despite these findings, little is known about the molecular alterations underlying efficency of statins on breast cancer. In this study, the effects of simvastatin on gene expression of cyclin D1, c-myc and p53, in DMBA-induced mammary tumors of mice was investigated and compared with tamoxifen as a commonly used drug in the treatment of breast cancer.

\section{Materials and methods}

\section{Animals and experimental design}

A total of 51 female albino mice with the average body weight of $23 \pm 0.9 \mathrm{~g}$ and aged 21 days were used in this study. The mice were bred in the laboratory breeding house of the Comparative and Experimental Medical Center Institute of Preventive Medicine, Shiraz, Iran. The animals were maintained under controlled room temperature $\left(24 \pm 4^{\circ} \mathrm{C}\right)$ with relative humidity (60\%), a $12 \mathrm{~h}$ light/dark cycle and were given commercial pelleted and water ad libitum. The protocol for this study was approved by our Institutional Animal Ethical Committee and was in accordance with the guidelines for the care and use of laboratory animals prepared by Shiraz University, Shiraz, Iran (IACUC no: 4687/63). They were acclimated for one week and were divided into two groups as follows: $\mathrm{N}$ group, healthy animals without DMBA administration $(n=7)$ and $D$ group, DMBAtreated group $(\mathrm{n}=44)$ that received DMBA $(50 \mathrm{mg} / \mathrm{kg}$ ) dissolved in sesame oil, orally once a week for the next 4 weeks, beginning at 5 weeks of age. The mice were weighed and palpated weekly for the appearance of mammary tumors 4 weeks after DMBA administration till to the end of the experiment. When tumors size reached $0.5 \mathrm{~cm}$ in the largest dimension, animals in group $\mathrm{D}$ were divided into three groups, 7 in each group (Karimi et al., 2018). Groups were labeled as follows: C, tumoric mice without treatment which were represented as the control group $(n=7) ; S$, tumeric mice with simvastatin treatment that received it by gavage with a dose of 80 $\mathrm{mg} / \mathrm{kg} /$ day for 4 consecutive weeks $(\mathrm{n}=7)$ and $\mathrm{T}$ : tumeric mice with tamoxifen treatment that received it by gavage with a dose of $50 \mathrm{mg} / \mathrm{kg} /$ day for 4 consecutive weeks $(n=7)$.

\section{Tissue sample preparation}

At the end of the experiment, all animals were sacrificed under deep anesthesia and the normal mammary glands and tumor tissues were removed, frozen in liquid nitrogen and kept at $-80^{\circ} \mathrm{C}$ until use.

\section{RNA Isolation and cDNA Synthesis}

All mammary glands and tumor tissues were used to extract total RNA using RNX-Plus Reagent (Cinnagen, Iran) and DNase treatment according to the manufacture's instructions. The quality and quantity of the extracted RNAs were evaluated by agarose gel electrophoresis and spectrophotometry. Concentrations of all extracts were normalized before cDNA synthesis. All RNA extracts were reverse 
Table 1: Oligonucleotide primers used for qRT-PCR analysis

\begin{tabular}{|c|c|c|c|}
\hline Gene & Primers sequences & $\begin{array}{l}\text { Annealing } \\
\text { Temperature }\left({ }^{\circ} \mathrm{C}\right)\end{array}$ & Product size (bp) \\
\hline \multirow{2}{*}{ GAPDH } & F: 5'-GGCAAATTCAACGGCACAGT-3' & \multirow{2}{*}{57} & \multirow{2}{*}{125} \\
\hline & R: 5'-CCTTTTGGCTCCACCCTTCA-3' & & \\
\hline C-myc & $\begin{array}{l}\mathrm{F}: \text { 5'-CTCCACTCACCAGCACAACT-3' } \\
\text { R: 5'-CGTTCCTCCTCTGACGTTCC-3' }\end{array}$ & 59 & 199 \\
\hline Cyclin D1 & $\begin{array}{l}\text { F: 5'-CACGGACTACAGGGGAGTTTTG-3' } \\
\text { R: 5'-GGTGTTCCATGGCGCGG-3' }\end{array}$ & 57.5 & 197 \\
\hline p53 & $\begin{array}{l}\text { F: 5'-CACAGCGTGGTGGTACCTTA-3' } \\
\text { R: 5'-AACCTCAAAGCTGTCCCGTC-3' }\end{array}$ & 59 & 177 \\
\hline
\end{tabular}

The primer sequence, annealing temperature and expected size of PCR products. GAPDH: glyceraldehyde-3-phosphate dehydrogenase.

Table 2: Primer optimization data. The best performing concentrations for each primer sets

\begin{tabular}{lll}
\hline Primer set & Optimum concentration (nM) & Efficiency \\
\hline GAPDH & F:600/R:600 & $100 \%$ \\
\hline C-myc & F:300/R:600 & $108.4 \%$ \\
\hline Cyclin D1 & F:400/R:400 & $108.75 \%$ \\
\hline p53 & F:400/R:400 & $109.6 \%$ \\
\hline
\end{tabular}

transcribed into cDNA in a total volume of $20 \mu \mathrm{l}$ using the RevertAidTM First Strand CDNA Synthesis Kit (Fermentas, Inc., USA) according to the manufacturer's instructions.

\section{Primer design and qRT-PCR experiment}

In this study, all primer sets were designed using Primer3 software based on standard rules of quantitative PCR primer design (Untergasser et al., 2012) and all sets were checked in database of SNPNCBI (Table 1). All primer sets were ordered from Cinnagen, Iran. Also, GAPDH (glyceraldehyde-3phosphate dehydrogenase) gene was used as a reference gene. For the best optimized and specified products in our qRT-PCR assay, primer optimization, efficiency test and melting curve analysis were performed (Table 2). The qRT-PCR was run on a Miniopticon instrument (BioRad, USA), using the SYBR Green PCR master kit (Parstous, Mashhad, Iran) according to the instructions provided by the manufacturer. The amplification cycles consisted of an initial denaturation step of 2 min at $95^{\circ} \mathrm{C}, 40$ cycles and a two-step amplification with $30 \mathrm{~s}$ at $95^{\circ} \mathrm{C}$ and $20 \mathrm{~s}$ at $59^{\circ} \mathrm{C}$. According to the efficiency results, relative quantitations were calculated by $2^{-(\Delta \Delta C t)}$ (Pfaffl, 2001).

\section{Statistical analysis}

Data were reported as mean $\pm S D$ and were analysed using one-way ANOVA followed by Tukey's test as a post hoc. The statistical level of $P<0.05$ was considered significant.

\section{Results}

Tumor parameters and the histopathological study of tumors were reported in our previous work (Karimi et al., 2018). In this study, the gene expression of cmyc, cyclin D1 and p53 in mammary glands and tumor tissues in different experimental groups were measured using real-time RT-PCR technique.

\section{Effect of simvastatin and tamoxifen on c-myc expression}

As shown in Figure 1, the results indicate a significant increase of c-myc expression in the control group in comparison to the normal group $(P<0.05)$. While simvastatin and tamoxifen-treated groups showed eduction in c-myc expression, which was significant in both groups compared to control group $(P<0.05)$, there was no significant difference between simvastatin and tamoxifen groups $(P>0.05)$.

\section{Effect of simvastatin and tamoxifen on cyclin D1 expression}

As shown in Figure 2, an increase in cyclin D1 


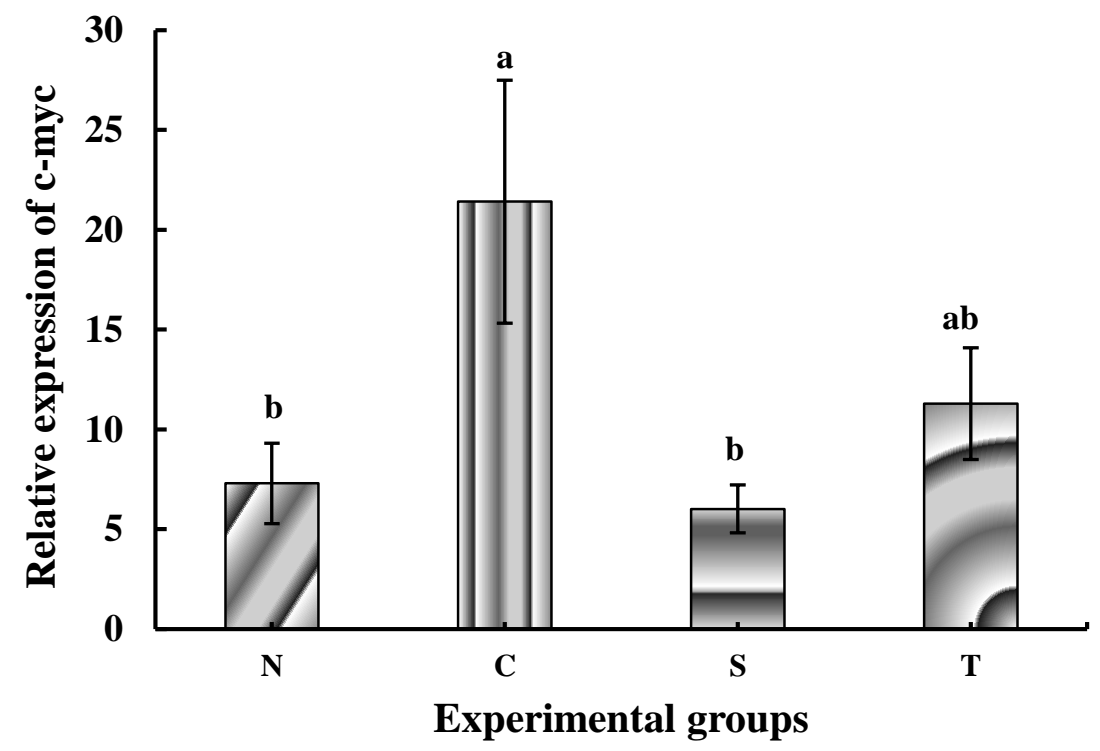

Fig.1. Relative expression of c-myc in all experimental groups using qRT-PCR analysis. Values are presented as mean $\pm S D$. Different letters show significant differences $(P<0.05)$ among groups. N: normal group; C: control group, received DMBA without treatment; $\mathrm{S}$ : simvastatin treated group with DMBA and simvastatin adminstration; $\mathrm{T}$ : tamoxifen treated group, recipient DMBA and tamoxifen.

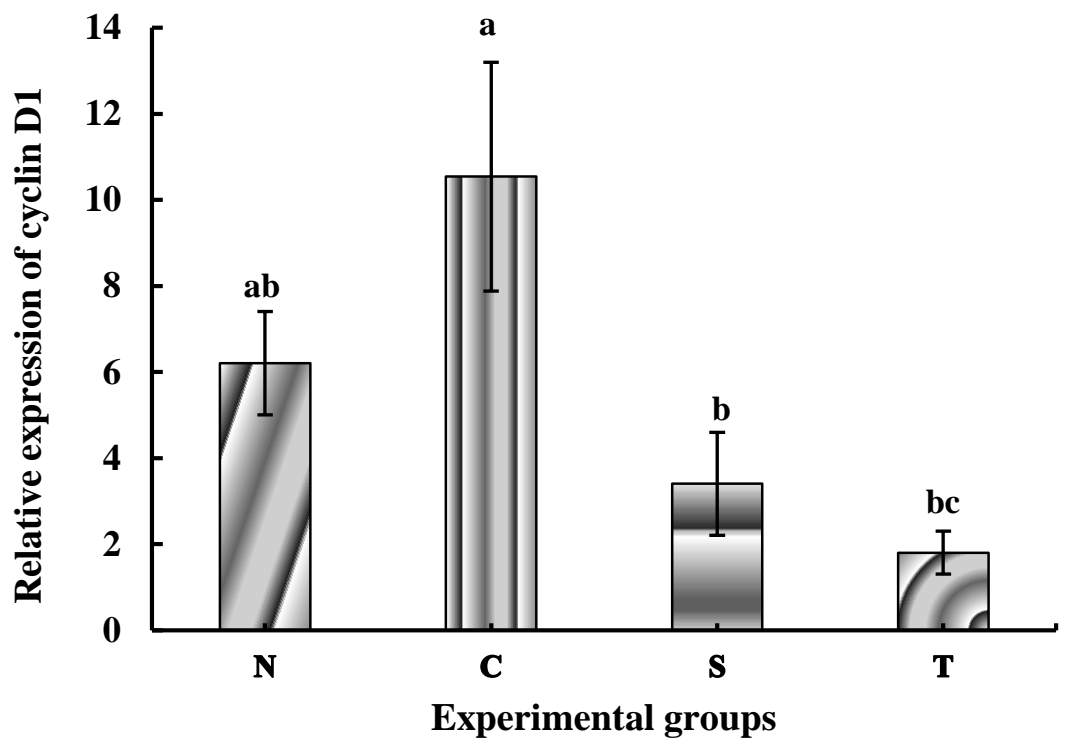

Fig.2. Relative expression of cyclin D1 in all experimental groups using qRT-PCR analysis. Values are presented as mean $\pm S D$. Different letters show significant differences $(P<0.05)$ among groups. N: normal group; C: control group, received DMBA without treatment; $\mathrm{S}$ : simvastatin treated group with DMBA and simvastatin adminstration; T: tamoxifen treated group, recipient DMBA and tamoxifen.

expression was found in the control group relative to normal group, but statistically was no significant ( $P>0.05)$. The messenger RNA expression levels of cyclin D1 in simvastatin and tamoxifen-treated groups were significantly lower than those in the control group $(P<0.05)$. Also, there was no significant difference between simvastatin and tamoxifen groups ( $P>0.05)$.

Effect of simvastatin and tamoxifen on p53

\section{expression}

In Figure 3, there was no significant change in the expression of p53 among groups $(P>0.05)$. However, its expression decreased in control and simvastatin groups compared with other groups $(P>0.05)$.

\section{Discussion}

Statins are common medications for treatment of hypercholesterolemia. Although many studies have shown the anticancer efficacy of statins (Riemsma 


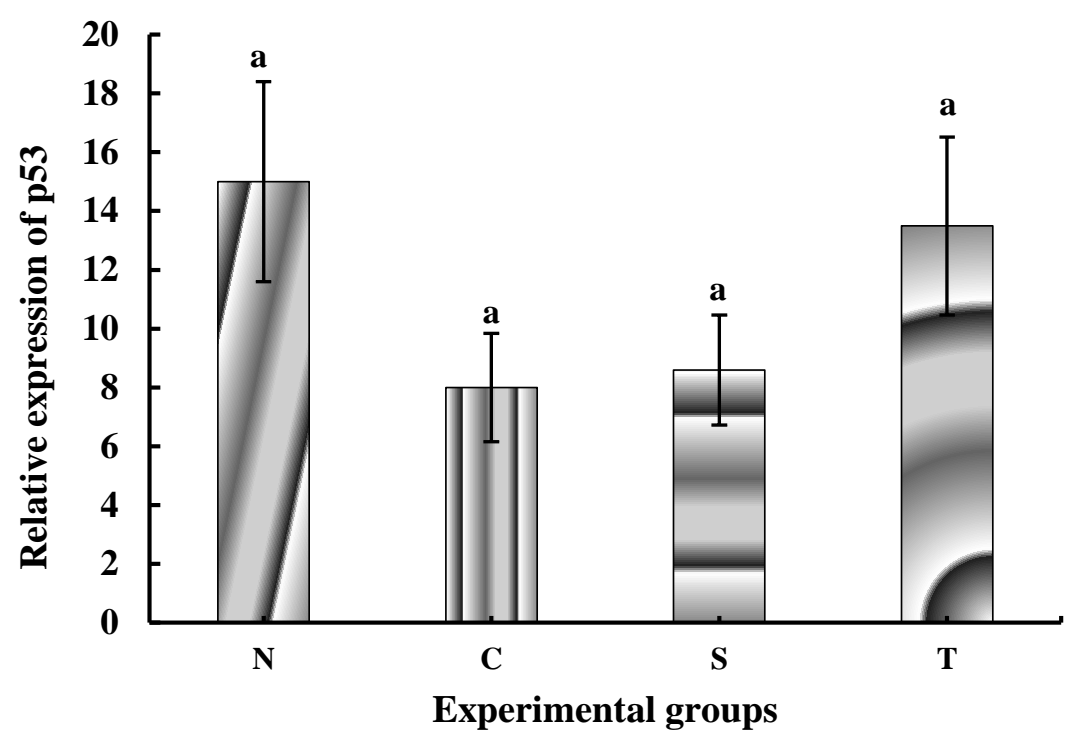

Fig. 3. Relative expression of p53 in all experimental groups using qRT-PCR analysis. Values are presented as mean $\pm S D$. Different letters show significant differences $(P<0.05)$ among groups. $\mathrm{N}$ : normal group; C: control group, received DMBA without treatment; $S$ : simvastatin treated group with DMBA and simvastatin adminstration; T: tamoxifen treated group, recipient DMBA and tamoxifen.

et al., 2010; Shen et al., 2015), their molecular mechanisms yet remain unknown. This study is the first research which investigated the effects of simvastatin on the gene expression of cyclin D1, Cmyc and p53 in DMBA-induced mammary tumors of mice.

Cell cycle progression is one of the important changes associated with proliferating tumoric cells and understanding this provides rational targets for cancer therapy (Meeran and Katiyar, 2008). Cyclin D1 is one of the cell-cycle related cyclins whose activity is required for the G1/S transition phase and regulation of cell proliferation (Kim and Diehl, 2009). More than $50 \%$ of human breast cancers showed over-expression of cyclin D1 (Roy, 2006). It is reported that the over-expression of cyclin D1 in the tumors of DMBA-induced breast cancer, is associated with the activation of NF-KB and Wnt pathway as up-stream regulators of cyclin D1 expression (Currier et al., 2005). Furthermore, activation of the Ras signaling pathway can stimulate the expression of cyclin D1 (Feldt et al., 2015). In the present study, the levels of cyclin D1 mRNA increased in tumors of the control group in comparison to normal group which is in line with previous studies (Currier et al., 2005; Papaconstantinou et al., 2006). It is evidenced that $\mathrm{H}$-ras point mutations are common events detected in DMBAinduced mammary tumorigenesis (Currier et al., 2005). Therefore, over-expression of cyclin D1 in the present study can be related to Ras signalling activation. The results showed that in tumors of simvastatin and tamoxifen-treated groups, cyclin D1 expression reduced in comparison to tumors of control group which may be a mechanism for antiproliferative effects of simvastatin against breast cancer. Consistent with the results of this study, Shen et al. (2015) demonstrated the inhibitory effect of simvastatin on the proliferation of breast cancer cell lines by affecting cell cycle and down-regulation of cyclin D1 and CDKs expression. On the other hand, the anti-proliferative effects derived from statins may be attributed to the inhibition of isoprenoid synthesis which is important in the prenylation of proteins implicated in intracellular signalling pathway, particularly in Ras/Rho superfamily. Therefore, inhibiting isoprenylation of the Ras protein by statins may be suggested as a possible mechanism that involves in the prevention of the cyclin D1 expression (Feldt et al., 2015).

C-myc is another direct target for transactivation by the Wnt signaling pathway (de Oliveira et al., 2015). In the present study, higher expression of c-myc has been detected in tumors of control group in comparison to the normal mammary glands of normal group and its expression is modulated in treated groups. In 2012, Takwi and colleagues indicated that lovastatin reduces c-myc expression and upregulates miR-33b expression in medulloblastoma cells. They explained that miR-33b acts as the potent 
tumor suppressor which reduces c-myc expression and negatively affects the cell cycle progression and proliferation. It is important to note that c-myc participates in many signaling pathways including Ras, Bcl-2 and factors that inactivate p53 and repress the induction of several p53 targets such as p21 and gadd45 and it leads to reduction of p53-induced apoptosis (Hulit et al., 2001).

The p53 is an important factor in many intracellular pathways. It serves an important roles in DNA repair, cell growth arrest, induction of apoptosis and inhibition of angiogenesis (Wawryk- Gawda et al., 2014). In immunohistochemical evaluation of the previous study on mammary tumors induced by DMBA in mice, no over-expression of p53 was observed. However, the sequencing of its gene confirmed the existence of wild type of p53 in DMBAinduced tumors (Jerry et al., 1994). Our results show that there is no significant change in the expression of p53 between the control and normal groups and it is in line with the study by Jerry's et al. (1994). Similarly, loss of expression of wild-type of p53 has been reported in DMBA-induced oral carcinogenesis in the hamster buccal pouch model. In the present study, tamoxifen-treated group showed a nonsignificant increase in the expression of p53 compared with the control group. However, in simvastatin group, its expression is similar to control group. The result is in agreement with the study by Koyuturk et al. (2007). They indicated that the treatment of ER-positive MCF-7 cells (with wild-type of p53) and MDA-MB 231 cells (with mutant p53) with simvastatin for 24 hours did not alter in the expression of p53 and induced apoptosis via involvement of JNK pathway. However, Li et al. (2015) showed that fluvastatin inhibited proliferation of hypoxic human umbilical vein endothelial cells by elevating of p27 and p53 expression and reduces levels of cyclin B1, cyclin D1 and VEGF expression. Pääjärvi et al. (2005) explained that the effects of statins on Mdm2/p53 regulation in DNA-damaged HepG2 cells. They concluded pravastatin induces phosphorylation of Mdm2 on Ser166 and thereby, facilitates degradation of Mdm2/p53 complex in cells stressed by DNA damaging agents.

\section{Conclusion}

In conclusion, the significant decrease in the expression of cyclin D1 and c-myc oncogenes in the simvastatin-treated group in comparison to control group may be suggested as a possible mechanism for anti-tumor effects of simvastatin in DMBA-induced breast cancer. Further efforts are needed to elucidate other mechanisms of simvastatin involved in the antibreast cancer effect.

\section{Acknowledgments}

This research was financially supported by Shiraz University Research Council.

\section{Conflict of interest}

The authors declare that they have no conflicts of interest.

\section{References}

Ashrafi M, Bathaie SZ, Abroun S. High expression of cyclin $\mathrm{D} 1$ and p21 in N-nitroso-N-methylurea-induced breast cancer in wistar albino female rats. Cell $\mathrm{J}$ (Yakhteh) 2012; 14: 193-202.

Beckwitt CH, Brufsky A, Oltvai ZN, Wells A. Statin drugs to reduce breast cancer recurrence and mortality. Breast Cancer Res 2018; 20: 144. https://doi.org/10.1186/ s13058-018-1066-z

Campbell MJ, Esserman LJ, Zhou Y, Shoemaker M, Lobo $\mathrm{M}$, Borman $\mathrm{E}$, et al. Breast cancer growth prevention by statins. Cancer Res 2006; 66: 8707-14. https://doi.org/ 10.1158/0008-5472.CAN-05-4061

Chan KK, Oza AM, Siu LL. The statins as anticancer agents. Clin Cancer Res 2003; 9: 10-9.

Currier N, Solomon SE, Demicco EG, Chang DL, Farago $M$, Ying $H$, et al. Oncogenic signaling pathways activated in DMBA-induced mouse mammary tumors. Toxicol Pathol 2005; 33: 726-37. https://doi.org/ 10.1080/01926230500352226

de Leon MP. Recent results in cancer research. In: Familial and hereditary tumors. Springer-Verlag, 1994, p. 35-47. https://doi.org/10.1007/978-3-642-85076-9_4

Dulak J, Józkowicz A. Anti-angiogenic and antiinflammatory effects of statins: relevance to anti-cancer therapy. Curr Cancer Drug Targets 2005; 5: 579-94. https://doi.org/10.2174/156800905774932824

Feldt M, Bjarnadottir O, Kimbung S, Jirström K, Bendahl PO, Veerla $S$, et al. Statin-induced anti-proliferative effects via cyclin D1 and p27 in a window-of-opportunity breast cancer trial. J Transl Med 2015; 13: 133. https://doi.org/10.1186/s12967-015-0486-0

Ghoncheh M, Pournamdar Z, Salehiniya H. Incidence and mortality and epidemiology of breast cancer in the world. Asian Pac J Cancer Prev 2016; 17: 43-6. https://doi.org/10.7314/APJCP.2016.17.S3.43

Graaf MR, Beiderbeck AB, Egberts AC, Richel DJ, Guchelaar HJ. The risk of cancer in users of statins. J Clin Oncol 2004; 22: 2388-94. https://doi.org/10.1200/ JCO.2004.02.027 
Hulit J, Di Vizio D, Pestell RG. Inducible transgenics. New lessons on events governing the induction and commitment in mammary tumorigenesis. Breast Cancer Res 2001; 3: 209-212. https://doi.org/10.1186/bcr297

Jerry DJ, Butel JS, Donehower LA, Paulson EJ, Cochran C, Wiseman RW, et al. Infrequent p53 mutations in 7, 12dimethylbenz [a] anthracene-induced mammary tumors in BALB/c and p53 hemizygous mice. Mol Carcinogen 1994; 9: 175-83. https://doi.org/10.1002/mc.2940090309

Karimi B, Ashrafi M, Shomali T, Yektaseresht A. Therapeutic effect of simvastatin on DMBA-induced breast cancer in mice. Fund Clin Pharmacol 2018; 33: 84-93. https://doi.org/10.1111/fcp.12397

Kim JK, Diehl JA. Nuclear cyclin D1: an oncogenic driver in human cancer. J Cell Physiol 2009; 220: 292-6. https://doi.org/10.1002/jcp.21791

Koyuturk M, Ersoz M, Altiok N. Simvastatin induces apoptosis in human breast cancer cells: p53 and estrogen receptor independent pathway requiring signalling through JNK. Cancer Lett 2007; 250: 220-8. https://doi.org/10.1016/j.canlet.2006.10.009

Li X, Liu X, Xu Y, He Y, Liu J, Xie M. Expression profile of apoptotic and proliferative proteins in hypoxic HUVEC treated with statins. Int J Oncol 2015; 46: 677-84. https://doi.org/10.3892/ijo.2014.2780

Martin AM, Weber BL. Genetic and hormonal risk factors in breast cancer. J Natl Cancer Inst 2000; 92: 1126-35. https://doi.org/10.1093/jnci/92.14.1126

Meeran SM, Katiyar SK. Cell cycle control as a basis for cancer chemoprevention through dietary agents. Front Biosci 2008; 13: 2191-2202. https://doi.org/10.2741/ 2834

Miller DM, Thomas SD, Islam A, Muench D, Sedoris K. cMyc and cancer metabolism. Clin Cancer Res 2012; 18: 5546-5553. https://doi.org/10.1158/1078-0432.CCR-120977

Musgrove EA, Caldon CE, Barraclough J, Stone A, Sutherland RL. Cyclin $D$ as a therapeutic target in cancer. Nat Rev Cancer 2011; 11:558-72. https://doi.org/ 10.1038/nrc3090

de Oliveira KD, Avanzo GU, Tedardi MV, Rangel MM, Avanzo JL, et al. Chemical carcinogenesis by DMBA (7, 12-dimethylbenzanthracene) in female BALB/c mice: new facts. Braz J Vet Res 2015; 52: 125-33. https://doi.org/10.11606/issn.1678-4456.v52i2p125-133

Ozaki T, Nakagawara A. Role of p53 in cell death and human cancers. Cancers 2011; 3: 994-1013. https://doi.org/10.3390/cancers3010994

Pääjärvi G, Roudier E, Crisby M, Hogberg J, Stenius U. HMG-CoA reductase inhibitors, statins, induce phosphorylation of Mdm2 and attenuate the p53 response to DNA damage. The FASEB journal 2005; 19: 476-8. https://doi.org/10.1096/fj.04-2745fje

Papaconstantinou AD, Shanmugam I, Shan L, Schroeder IS, Qiu C, Yu M, et al. Gene expression profiling in the mammary gland of rats treated with 7, 12-dimethylbenz [a] anthracene. Int $\mathrm{J}$ Cancer 2006; 118: 17-24. https://doi.org/10.1002/ijc.21247

Pfaffl MW. A new mathematical model for relative quantification in real-time RT-PCR. Nucleic Acids Res 2001; 29: 2002-7. https://doi.org/10.1093/nar/29.9.e45

Riemsma R, Forbes CA, Kessels A, Lykopoulos K, Amonkar MM, Rea DW, et al. Systematic review of aromatase inhibitors in the first-line treatment for hormone sensitive advanced or metastatic breast cancer. Breast Cancer Res Treat 2010; 123: 9-24. https://doi.org/10.1007/s10549-010-0974-0

Roy PG, Thompson AM. Cyclin D1 and breast cancer. The Breast 2006; 15: 718-27. https://doi.org/10.1016/ j.breast.2006.02.005

Shen YY, Yuan Y, Du YY, Pan YY. Molecular mechanism underlying the anticancer effect of simvastatin on MDA MB 231 human breast cancer cells. Mol Med Rep 2015; 12: 623-30. https://doi.org/10.3892/mmr.2015.3411

Stancu C, Sima A. Statins: mechanism of action and effects. J Cell Mol Med 2001; 5: 378-87. https://doi.org/10.1111/j.1582-4934.2001.tb00172.x

Takwi AA, Li Y, Buscaglia LE, Zhang J, Choudhury S, Park $A K$, et al. A statin-regulated microRNA represses human c-Myc expression and function. Embo Mol Med 2012; 4: 896-909. https://doi.org/10.1002/emmm. 201101045

Untergasser A, Cutcutache I, Koressaar T, Ye J, Faircloth BC, Remm M, et al. Primer3-new capabilities and interfaces. Nucleic Acids Res 2012; 40: e115. https://doi.org/10.1093/nar/gks596

Wawryk-Gawda E, Chylińska-Wrzos P, Lis-Sochocka M, Chłapek K, Bulak K, Jędrych M, et al. P53 protein in proliferation, repair and apoptosis of cells. Protoplasma 2014; 251: 525-533. https://doi.org/10.1007/s00709013-0548-1 